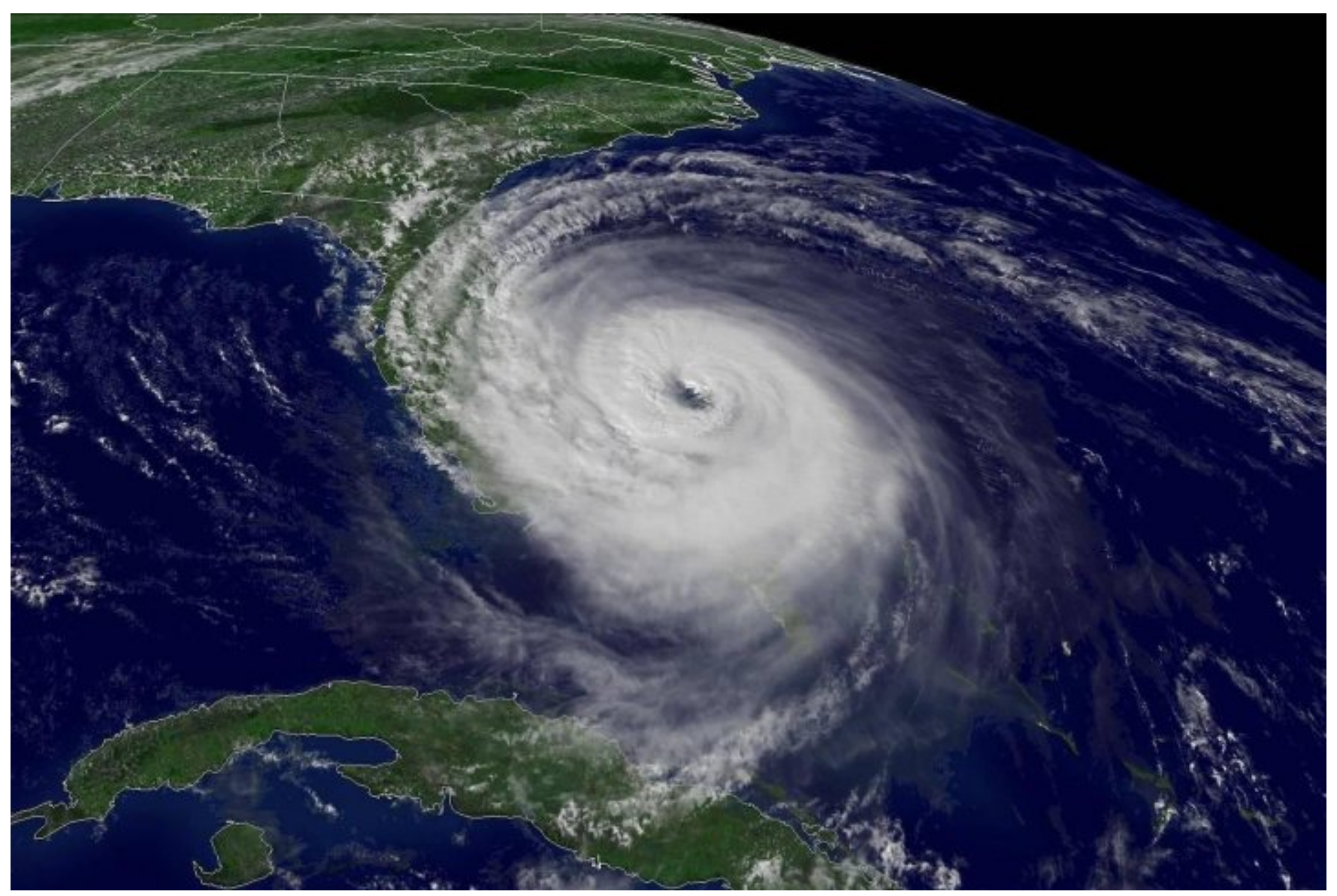

Chapter 2

\title{
Get the Right Tree Care Professional
}

Eliana Kampf, Astrid Delgado, Mary Duryea, Traci Partin and Edward Gilman
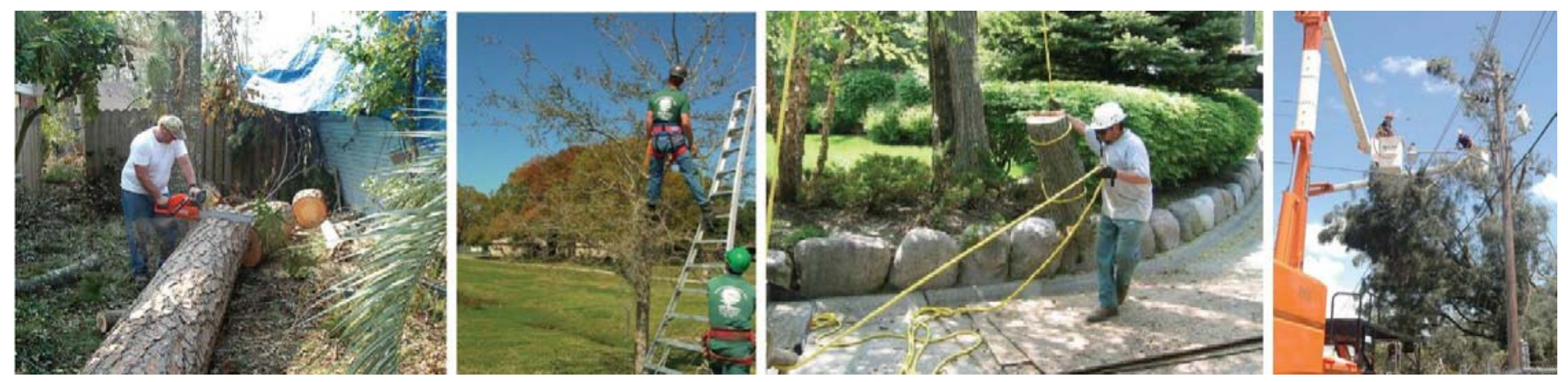

Urban Forest Hurricane Recovery Program http://treesandhurricanes.ifas.ufl.edu 


\section{Get the Right Tree Care Prolessional}

Eliana Kampf, Astrid Delgado, Mary Duryea, Traci Partin and Edward Gilman²

\section{What Situations Require a Professional?}

\section{Homeowner}

If you use a chain saw, work only on the ground. Get a professional for all other situations. Do not use ladders or ropes.

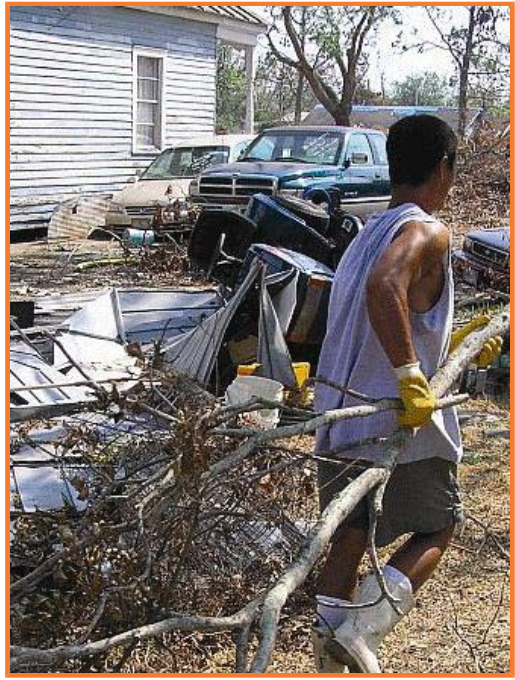

Figure 1. Homeowners can clear debris to help professionals perform their specialized work.

\section{Professional}

Tree care professionals with adequate equipment and insurance can handle these situations.

- Taking trees down in open areas.

- Removing dead or hazardous limbs.

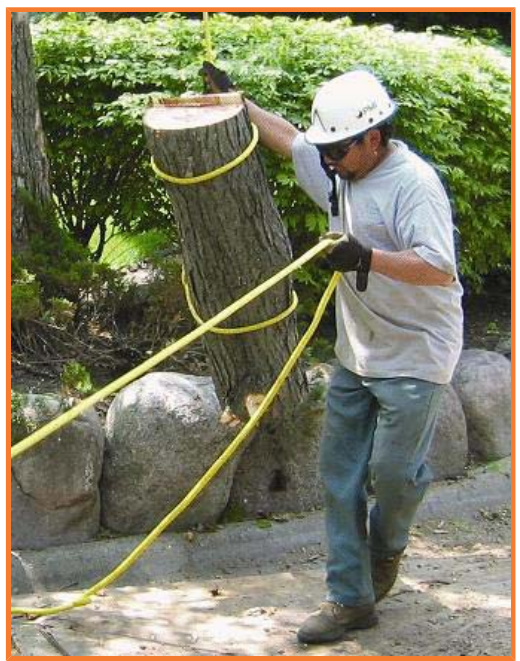

Figure 2. If there is no room to safely fell a tree, the situation requires professional help.

1. This document is FOR 116, one of the Urban Forest Hurricane Recovery series of the School of Forest Resources and Conservation and the Environmental Horticulture Department, Florida Cooperative Extension Service, Institute of Food and Agricultural Sciences, University of Florida. Original publication date January 2007. Visit the EDIS Web Site at http://edis.ifas.ufl.edu and http://treesandhurricanes.ifas.ufl.edu.

2. Eliana Kampf, Urban Forester, School of Forest Resources and Conservation; Astrid Delgado, Urban Forester Landscaping Specialist, School of Forest Resources and Conservation; Mary Duryea, Professor, School of Forest Resources and Conservation and Associate Dean for Research, IFAS; Traci Partin, Horticultural Information Specialist, Department of Environmental Horticulture; Edward Gilman, Professor, Department of Environmental Horticulture; University of Florida, Institute of Food and Agricultural Sciences, Gainesville, FL 32611

The Institute of Food and Agricultural Sciences (IFAS) is an Equal Employment Opportunity - Affirmative Action Employer authorized to provide research, educational information and other services only to individuals and institutions that function without regard to race, creed, color, religion, age, disability, sex, sexual orientation, marital status, national origin, political opinions or affiliations. For information on obtaining other extension publications, contact your county Cooperative Extension Service office. Florida Cooperative Extension Service / Institute of Food and Agricultural Sciences / University of Florida / Larry R. Arrington, Dean. 


\section{Certified Arborist}

These situations require advanced training and are best handled by ISA certified arborists.

- Removing a leaning tree or broken limb that is near a house or other potential target.

- Reaching limbs that require climbing.

- Restoring a damaged tree that could be saved.

- Pruning to promote good structure.

\section{Electrical Hazards}

Trees can uproot underground utilities and tear down power lines during hurricanes. The combination of electrical wires and flooding creates a hazardous environment that requires extreme caution. Only qualified line-clearance arborists should work near electrical utilities.

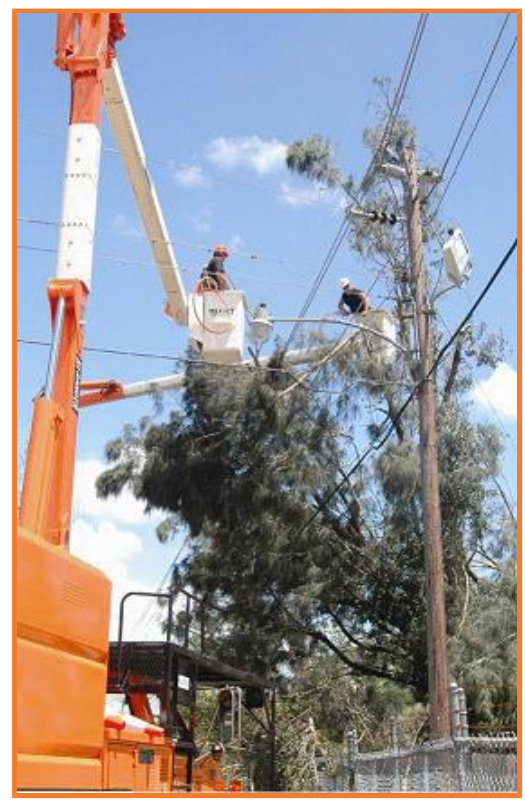

Figure 3. Working near power lines is an especially dangerous situation.

- Call the power company to report tree limbs that have fallen on a power line.

- Assume all power lines are energized and do not touch. Improper use of generators may energize lines without warning.

- Beware! Electrocution may occur if any part of your body touches a conductor (water, tool, tree branch, metal fence, etc.) in contact with an energized power line.

\section{Hiring an Arborist}

Hiring an arborist is a worthwhile investment. Trees increase property value when they are well maintained but can be a liability if poorly pruned or unhealthy.



Figure 4. Get the right tree care professional.

Beware of scams! Unqualified individuals wanting to make a quick dollar may bring chain saws and equipment to help clean up after the storm. However, qualified arborists from around the country also come to help. Learn to identify the qualified arborists because unqualified workers may get hurt or cause irreparable damage to trees.

\section{Use these questions to help you find a qualified arborist:}

\section{Insurance}

1. Are you insured for property damage, personal liability, and worker's compensation?

If you hire an uninsured company, you may be held responsible for medical bills and lost wages for injured workers. 


\section{Professional}

2. Are you certified by the International Society of Arboriculture (ISA)?

Being certified requires professional experience and knowledge of the best techniques in the industry. Arborists attend training courses and continuing education classes to learn the latest research.

3. What are the ANSI Z133.1 and ANSI A300 guidelines?

The American National Standards Institute (ANSI) prints these two guidelines, with which all tree care professionals should be familiar. ANSI Z133.1 represents safety standards for tree care operations in the United States. ANSI A300 represents the best management practices in the industry for pruning and other tree care operations.

\section{Estimates}

4. What are the procedures involved, equipment used, price, and time frame?

Get more than one written estimate. Keep in mind that specialized equipment, qualified skills, and insurance will cost more. Good tree work is worth the additional investment; poor work may cost more in the long run.
To find an ISA certified arborist in your area, contact:

International Society of

Arboriculture (ISA)

http://www.isa-arbor.com

(217) 355-9411 or (888) 472-8733



Florida Chapter - ISA

http://www.floridaisa.org

(941) 342-0153

Florida Cooperative Extension Service

County Office

Florida Division of Forestry County Office 